\title{
VEGETATIVE RESCUE AND CUTTINGS PROPAGATION OF Araucaria angustifolia (Bertol.) Kuntze ${ }^{1}$
}

\author{
Ivar Wendling ${ }^{2}$ e Gilvano Ebling Brondani ${ }^{3}$
}

\begin{abstract}
Brazilian pine or araucaria (Araucaria angustifolia) is a coniferous tree with great economic, social and environmental importance in southern Brazil, being exploited for both wood production and for its edible pine nuts. However, no efficient cloning techniques are available and, therefore, the purpose of this study was to evaluate the effectiveness of vegetative rescue methods for cuttings propagation of the species. Shoots/cuttings were generated in two ways: 26 years old trees underwent coppicing and 20 years old trees had the primary branches on the upper third of crown pruned at 2, 20 and $50 \mathrm{~cm}$ from the main trunk. Orthotropic shoots were rooted after application of indole-3-butyric acid (IBA) at 0, 2, 4 and 6 g.L.- . Coppicing produced 47 cuttings per plant with $90 \%$ orthotropic shoots, while pruning resulted in 182 cuttings per plant with $44 \%$ orthotropic shoots. Rooting success indexes were low with no influence of IBA, although they are slightly superior to the ones available in the literature for the species, ranging from 12 to $30 \%$ for the coppice shoots and from 0 to $28 \%$ for the branches shoots. We conclude that both vegetative rescue techniques are viable and have potentially important applications. Coppicing is recommended for the propagation aiming the production of wood, while shoots derived from the side branches of the crown are more appropriate for seeds orchards formation.
\end{abstract}

Keywords: Brazilian pine; Cutting propagation; Clonal forestry.

\section{RESGATE VEGETATIVO E ESTAQUIA DE Araucaria angustifolia (Bertol.) Kuntze}

\begin{abstract}
RESUMO - A araucária, ou pinheiro-brasileiro (Araucaria angustifolia), é uma conífera subtropical de grande importância econômica, social e ambiental no Sul do Brasil, sendo explorada para produção de madeira e pinhão. No entanto, técnicas eficientes de clonagem não estão disponíveis e, assim, o objetivo deste estudo foi avaliar a efetividade de métodos de resgate vegetativo para estaquia da espécie. Brotações/estacas foram geradas de duas maneiras: árvores de 26 anos sofreram corte raso (decepa) e árvores de 20 anos tiveram seus ramos primários no terço superior da copa podados a 2, 20 e $50 \mathrm{~cm}$ do tronco principal. Brotações ortotrópicas foram enraizadas após a aplicação do ácido indol-3-butírico (AIB), a 0, 2, 4 e 6 g.L.1. A decepa produziu 47 estacas por planta, com 90\% de brotações ortotrópicas, enquanto a poda de galhos resultou em 182 estacas por planta, com 44\% de brotações ortotrópicas. Os índices gerais de enraizamento foram baixos, sem influência do AIB, embora sejam ligeiramente superiores àqueles disponíveis na literatura para a espécie, com variação de 12-30\% para as brotações de decepa e de 0-28\% para brotações de galhos da copa. Conclui-se que ambas as técnicas de resgate vegetativo são viáveis e têm aplicações potencialmente importantes. A decepa é indicada para a propagação visando à produção de madeira, enquanto brotações derivadas dos ramos laterais da copa são mais apropriadas para a formação de pomares de sementes.
\end{abstract}

Palavras-chave: Araucária; Estaquia; Silvicultura clonal.

\footnotetext{
${ }^{1}$ Recebido em 07.08.2013 aceito para publicação em 08.10.2014.

${ }^{2}$ Empresa Brasileira de Pesquisa Agropecuária, Centro Nacional de Pesquisa de Florestas, Colombo, PR - Brasil. E-mail: <ivar.wendling@embrapa.br>.

${ }^{3}$ Universidade Federal de Mato Grosso, Departamento de Engenharia Florestal, Cuiabá, MT - Brasil. E-mail: <gebrondani@yahoo.com.br>.
} 


\section{INTRODUCTION}

The Brazilian pine or araucaria (Araucaria angustifolia) was once widespread in southern Brazil, but has been in almost continuous decline since the early 1990 s due to a combination of clear-cutting and intensive exploitation (CARVALHO, 2003) and the species is today classified as vulnerable in the IUCN red list of threatened species (IUCN, 2013). Reforestation programs are limited both in number and success and part of these limitations may be related to the lack of information on many important ecological, biological and physiological aspects of the species (DUARTE et al., 2002; SOUSA and HATTEMER, 2003). Like most pine species, araucaria reproduces by seed. However, extensive propagation and restoration has been problematic because seeds lose their viability within a year of being collected (MOREIRA-SOUZA and CARDOSO, 2003), placing a high premium on the development of alternative propagation methods.

One potential solution is the development of largescale vegetative propagation methods, a commonly adopted alternative for species where sexual propagation is frequently ineffective (PIJUT et al., 2011). Such a system has the added advantage of conserving superior genotypes, maintaining valuable traits, and reducing the high risk period when the tree is small and fragile (CUEVAS-PEREZ et al., 1992). The development of a successful system of vegetative production will also allow producers to propagate plants with the same characteristics as the parent trees (ELDRIDGE et al., 1994) and, potentially, to engage in propagation throughout the year (ASSIS et al., 2004; XAVIER et al., 2009). Despite these potential advantages, scientists have so far been unable to develop an effective system of vegetative propagation for A. angustifolia preliminary attempts resulted in no more than $25 \%$ of cuttings becoming successfully rooted (IRITANI and SOARES, 1983), too low for development on a commercial scale.

The difficulties associated with developing an effective model of vegetative propagation in araucaria are not unique. Vegetative rescue of adult plants is a major challenge in clonal forestry due to the loss of morphogenic capacity over the course of ontogenetic aging. Potential solutions include the inducement of epicormic shoots from dormant buds formed during primary growth at the base of trees (HARTMANN et

Revista Árvore, Viçosa-MG, v.39, n.1, p.93-104, 2015 al., 2011), which can be used as propagating material (CHALUPA, 2002; PIJUT et al., 2011; WENDLING et al., 2013). Such induced shoots can be used as cuttings for adventitious rooting (XAVIER and SANTOS, 2002; HARTMANN et al., 2011) without the need for extensive damage to the parent tree. Several techniques have been developed for inducing shoots in dormant buds. The foremost of these is probably coppicing, which can be used in many forest species (ALMEIDA et al., 2007). Coppicing consists of making a shallow cut in the selected tree in order to induce juvenile shoots that can be subsequently removed and used for adventitious rooting. One of the drawbacks of this technique (i.e., induction of epicormic shoots) is a consequence of the so called 'gradient of juvenility', where shoots farther away from the base of the tree are less juvenile (HARTMANN et al., 2011). Thus, depending on the position of the shoot, there are different rhizogenic responses influenced by chronological, physiological and ontogenetic tree age (PIJUT et al., 2011).

Even if clonal propagules can be effectively induced, the success of the propagation system may be limited by rooting rate. Propagule rooting is influenced by endogenous and exogenous factors, such as ontogenetic and physiological state, propagule type, humidity, temperature, light incidence, substrate, nutritional and hormonal balance, as well as certain genes and enzyme activity (BASAK et al., 2000; LI et al., 2009; PIJUT et al., 2011). Nevertheless, the probability of successful rooting can be enhanced with growth regulators, such as auxins. One of the most effective and widely used auxins is indole-3-butyric acid (IBA), which has low toxicity, low mobility and high chemical stability (HARTMANN et al., 2011).

The general objective of this study was to develop an effective and viable method of vegetative propagation for Araucaria angustifolia. Specifically, we evaluated: (i) the effectiveness of different methods for inducing vegetative propagules in adult trees, and; (ii) the rooting success and the growth habit of cuttings obtained by different methods (see above) after application of IBA.

\section{MATERIALS AND METHODS}

\subsection{Experiment I - Basal shoots induction via coppicing}

In July 2006, 10 parent trees (i.e., five female and five male) of 26 years old established in a provenance and progeny test ( $3 \times 2 \mathrm{~m}$ spacing) in Paraná State, 
Brazil, underwent coppicing at approximately $20 \mathrm{~cm}$ above soil level. Survival of stumps, the number of shoots and cuttings produced per stump, cuttings type and growth habit of shoots were evaluated one year after coppicing. Three length classes (CCB) were used to classify shoots: class $1(5 \leq \mathrm{CCB}<37 \mathrm{~cm})$, class $2(37 \leq \mathrm{CCB}<68 \mathrm{~cm})$ and class $3(68 \leq \mathrm{CCB} \leq 100 \mathrm{~cm})$. The total number of non-apical cuttings $(12 \pm 2 \mathrm{~cm})$ and the shoots were also classified as orthotropic, without definition and plagiotropic. Orthotropic shoots are those with vertical growth (normal), plagiotropic are those with oblique or horizontal growth (abnormal) and shoots without definition were those where no clear growth habit could be identified. The experiment was conducted in a completely randomized design with 10 replicates and one stump per replicate.

\subsection{Experiment II - Crown shoots induction in pruned primary branches}

In September 2007, 12 parent trees of approximately 20 years old (set in a simple line, spaced $3 \mathrm{~m}$ from each other) had their primary branches of the upper third of crown pruned (around 40 branches per tree). Branches were pruned at 2, 20 and $50 \mathrm{~cm}$ from the stem. At 70, 110 and 160 days after pruning, the number of shoots was evaluated according to three length classes (CCB): class 1 ( $1 \mathrm{~d}$ " $\mathrm{CCB}<6 \mathrm{~cm})$, class $2(6 \mathrm{~d}$ " $\mathrm{CCB}<12 \mathrm{~cm})$ and class 3 (CCB e" $12 \mathrm{~cm}$ ). At 220 days after pruning, the total number of non-apical cuttings produced $(12 \pm 2 \mathrm{~cm})$ and the shoots were classified as orthotropic, without definition or plagiotropic (as described in Experiment I). The experiment was conducted in a randomized block design with four blocks and one plant per plot.

\subsection{Experiment III - Rooting cuttings of basal shoots}

The shoots induced from coppicing (Experiment I) with orthotropic growth habit were collected (July 2007 ) and cuttings ( $12 \pm 2 \mathrm{~cm}$ ) were prepared by removing one third of the base needles. The cuttings were dipped into a solution of sodium hypochlorite ( $1 \%$ of active chlorine) for 5 minutes, washed under tap water, and then treated with systemic fungicide Benomyl (1 g.L.-1) for 10 minutes for aseptic treatment. After washing under tap water again, the basal region of each cutting was immersed for 10 seconds in hydro-alcoholic solution $(1: 1 \mathrm{v} / \mathrm{v}$, water: alcohol) with different concentrations of indole-3-butyric acid (IBA): T1: water immersion,
T2: immersion in alcohol + water, T3: 2 g.L. $\mathrm{L}^{-1}, \mathrm{~T} 4: 4$ g.L. $\mathrm{L}^{-1}$ and T5: 6 g.L $\mathrm{L}^{-1}$ IBA. Finally, each cutting was inserted into a $170 \mathrm{~mL}$ tube, with vermiculite and carbonized rice hulls $(1: 1, \mathrm{v} / \mathrm{v})$ and placed in a greenhouse at a temperature of $25 \pm 2{ }^{\circ} \mathrm{C}$ and a relative humidity of above $80 \%$.

After 90 days in greenhouse, the cuttings were placed in a shade house (i.e., $50 \%$ shade) for 30 days for acclimatization. Finally, the cuttings were exposed to full sunlight for 50 days for hardening and growth. Cutting survival was evaluated in the greenhouse and shade house exit. Rooting success, height and diameter of the rooted cuttings were evaluated at the end of the full sunlight period. The number of shoots per cutting was determined at the exit of greenhouse and shade house and at the full sunlight area. The experiment was conducted in a completely randomized design with four concentrations of IBA and five replicates of 10 cuttings.

\subsection{Experiment IV - Rooting cuttings from crown shoots}

Shoots from the crown (i.e., from Experiment II) were selected from three trees to evaluate the rooting capacity. Cuttings taken from orthotropic shoots (in May 2008) were prepared and subjected to the same procedures and IBA treatments described in Experiment III, without water immersion. Survival was assessed at the end of the greenhouse phase. Rooting and total length of exposed roots at the bottom were assessed at 170 days. A completely randomized design with four concentrations of IBA was used, with five replicates of five cuttings.

\subsection{Statistical analysis}

Sampled data were tested for normality with the Shapiro-Wilk test $(p<0.05)$ and Bartlett's test $(p<0.05)$, and transformed when necessary by Box-Cox test. They were then subjected to analysis of variance (ANOVA, $p<0.01$ and $p<0.05)$. According to the significance of the ANOVA, the qualitative factors were compared by Tukey test $(\mathrm{p}<0.05)$.

\section{RESULTS}

\subsection{Experiment I - Basal shoots induction via coppicing}

One year after coppicing, $60 \%$ of pruned trees survived, and all survivors had shoots (data not shown). Shoots were mostly between 5 and $37 \mathrm{~cm}$ length (class 1) for female trees and between 5 and $68 \mathrm{~cm}$ (classes

Revista Árvore, Viçosa-MG, v.39, n.1, p.93-104, 2015 
1 and 2) for male trees (Figure 1A). Out the total number of shoots obtained from stumps, approximately $90 \%$ showed an orthotropic growth habit (data not shown). On average, female trees produced 44 shoots and male trees 39, although this difference was not significant. Male trees produced more apical cuttings (30) (Figure $1 \mathrm{~B})$ as a result of the higher number of shoots produced in large size classes (2 and 3) (Figure 1A). Female trees produced more non-apical cuttings (25). On average, 47 cuttings were obtained per stump (26 apical and 21 non-apical), with no significant difference between these types of cuttings.

\subsection{Experiment II - Shoot induction in pruned primary branches}

The pruning of branches at 20 and $50 \mathrm{~cm}$ produced more shoots than branches pruned at $2 \mathrm{~cm}$ at all evaluation period and for practically all shoot classes (Figure 2A, $2 \mathrm{~B}$ and $3 \mathrm{~A}$ ). The same trend can be observed in the total number of shoots per tree. At 70 days after pruning (Figure 2A), the vast majority of shoots were between $1-6 \mathrm{~cm}$. At 110 days (Figure 2B) and 160 days (Figure 2C), shoots of all size classes were present, there was a significant increase in shoots in the $6.1-12 \mathrm{~cm}$ class and the $>12 \mathrm{~cm}$ class at 110 days, which was even more pronounced at 160 days.

By the standard used for rooting $(12 \pm 2 \mathrm{~cm})$, no suitable cuttings were obtained from the 1-6 cm class of shoots and a small number from the 6.1 to $12 \mathrm{~cm}$ class was obtained. As might be expected, shoots over
$12 \mathrm{~cm}$ produced the highest number of cuttings with the best production associated with pruning at $50 \mathrm{~cm}$ (153 per tree) and at $20 \mathrm{~cm}$ (112 per tree) from the trunk (Figure 2D). The same pattern was observed for total orthotropic cuttings, with 17,129 and 182 cuttings produced per tree for pruning at 2, 20 and $50 \mathrm{~cm}$ of the trunk, respectively.

At 220 days, pruning at $50 \mathrm{~cm}$ resulted in the largest amount and percentage of orthotropic shoots (61 shoots), i.e. $44 \%$ of shoots with this growth habit (Figure $3 \mathrm{~A}$ and B). Pruning at 2 and $20 \mathrm{~cm}$ from the trunk resulted in superiority predominance of shoots with no definition followed by orthotropic shoots. In general, the amount of plagiotropic shoots was significantly lower than orthotropic shoots and those with no definition, with the exception of shoots produced at $50 \mathrm{~cm}$ (Figure 3A and 4B).

\subsection{Experiment III - Rooting cuttings of basal shoots}

In general, the application of IBA did not enhance survival and rooting. Survival at the greenhouse exit (SCV) ranged from 44 to $74 \%$, with no significant difference between treatments - with the exception of 3 g.L $\mathrm{L}^{-1}$ which had significantly lower values than the control (water only) (Figure 4A). At the shade house exit (SCS), the results were similar with the exception of 1 g.L $\mathrm{L}^{-1}$, which showed significantly lower survival than water and 6 g. $\mathrm{L}^{-1}$ : survival values ranged from $18 \%\left(1 \mathrm{~g} . \mathrm{L}^{-1}\right)$ to $42 \%$ (water), with an average reduction of $33.2 \%$ compared to the greenhouse. After exposure to full sunlight (APS),
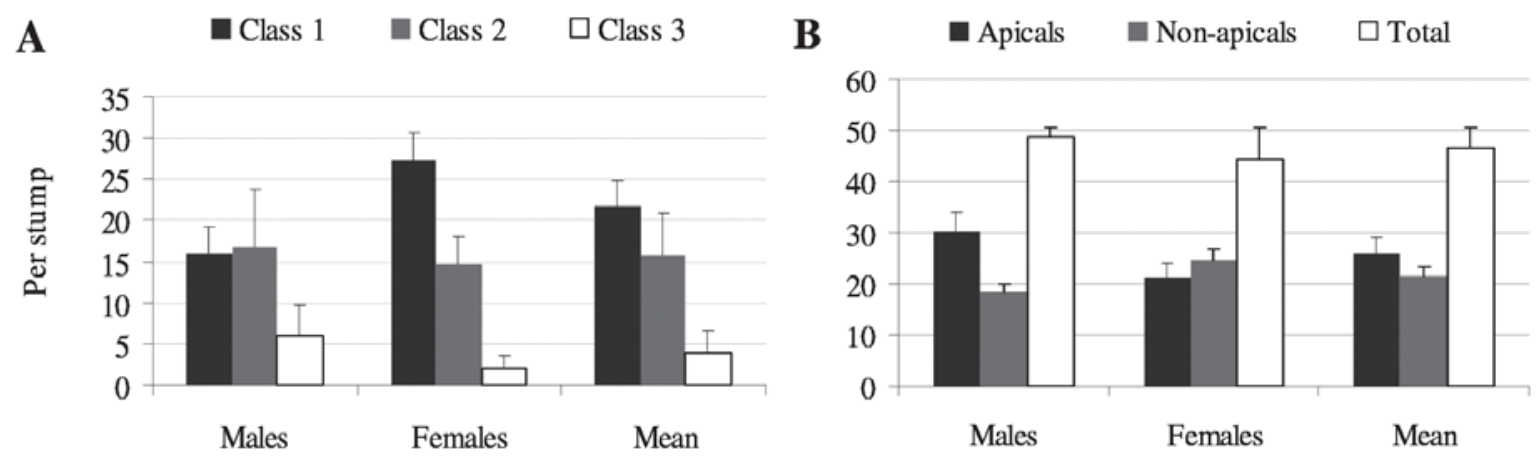

Figure 1 - Number of shoots produced per class (A) and number of non-apical and apical cuttings produced (B) per stump of male and female plants of Araucaria angustifolia, one year after coppicing. Where: Class $1=5 \leq \mathrm{CCB}<37 \mathrm{~cm}$; Class $2=37 \leq \mathrm{CCB}<68 \mathrm{~cm}$ and; Class $3=68<\mathrm{CCB} \leq 100 \mathrm{~cm}$.

Figura 1 - Número de brotações produzidas por classe de tamanho (A) e número de estacas intermediárias e apicais produzidas (B) por cepa de plantas macho e fêmea de Araucaria angustifolia, um ano após a decepa. Onde: Classe $1=$ $5 \leq C C B<37 \mathrm{~cm}$; Classe $2=37 \leq C C B<68 \mathrm{~cm}$ e; Classe $3=68 \leq C C B \leq 100 \mathrm{~cm}$.

Revista Árvore, Viçosa-MG, v.39, n.1, p.93-104, 2015 
$\mathbf{A}$

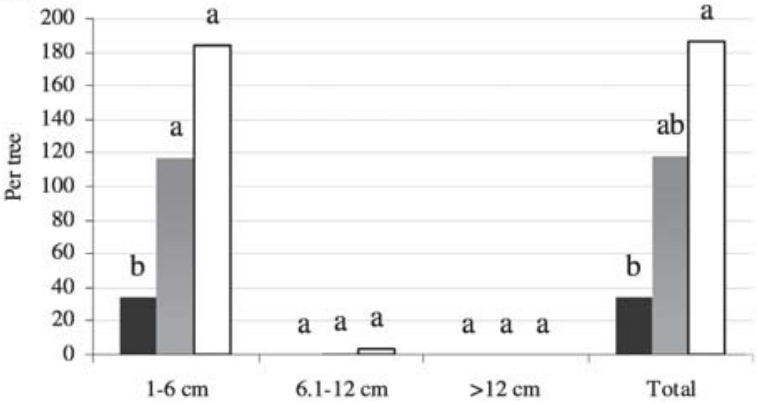

C

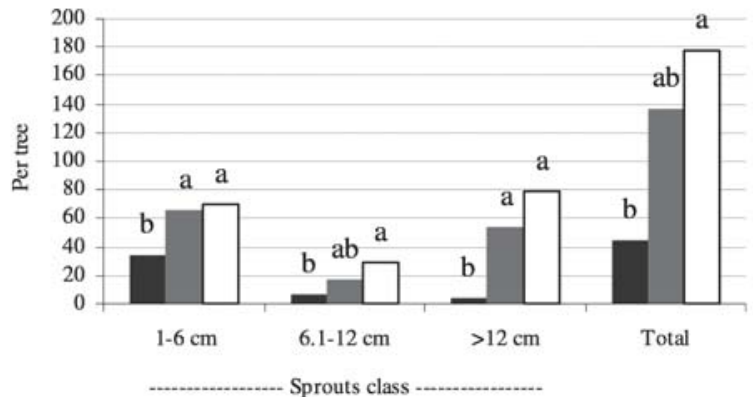

$\mathbf{B}$

arune at $2 \mathrm{~cm}$ : Prune at $20 \mathrm{~cm} \square$ Prune at $50 \mathrm{~cm}$

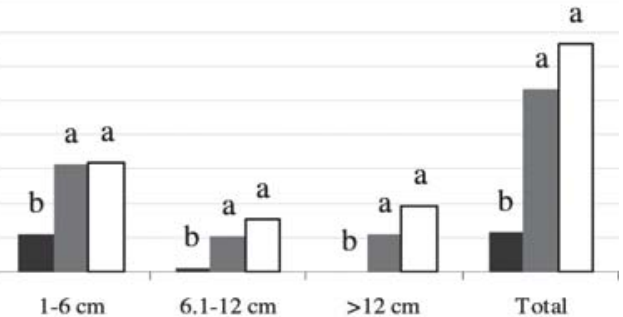

D

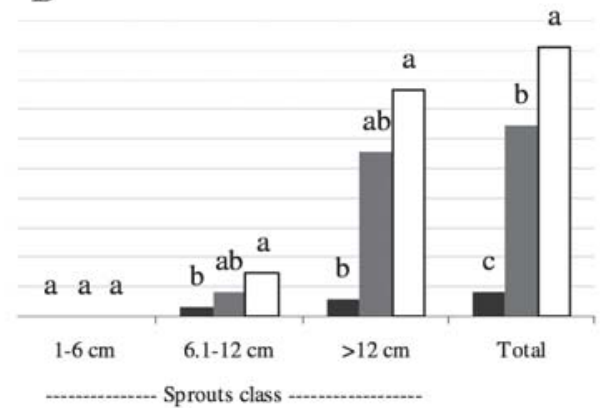

Figure 2 - Number of shoots produced at 70 (A), 110 (B) and $160(\mathrm{C})$ days, and the number of orthotropic cuttings produced at 220 days after pruning (D) per class and pruned tree of Araucaria angustifolia. Means followed by the same letter among different pruning sizesdo not significantly differ (Tukey test at $5 \%$ ).

Figura 2 - Número de brotações emitidas aos 70 (A), 110 (B) e 160 (C) dias e número de estacas ortotrópicas produzidas aos 220 dias após a poda (D) por classe de broto e matriz de Araucaria angustifolia. Médias seguidas pela mesma letra entre os diferentes tamanhos de poda não diferem entre si pelo teste de Tukey a $5 \%$.

$\mathbf{A}$

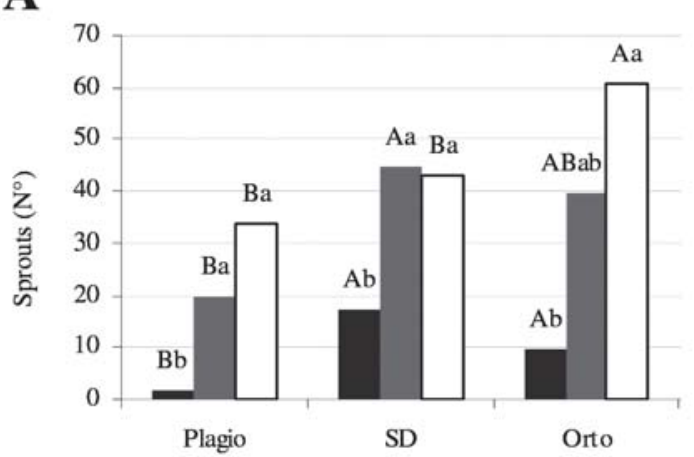

Growth habit

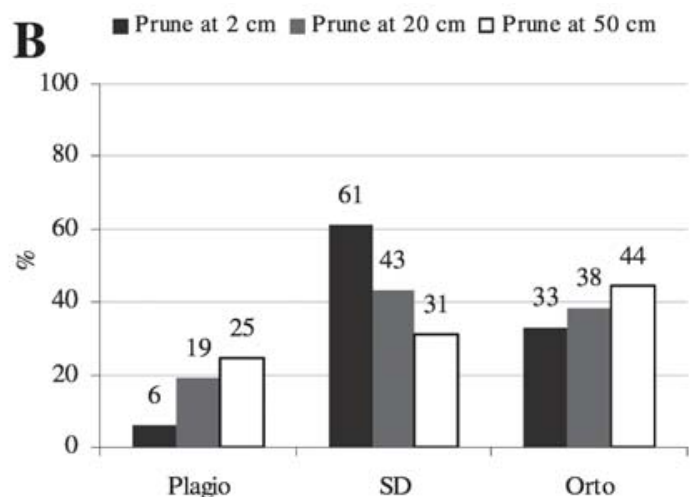

Growth habit

Figure 3 - Growth habit of shoots of Araucaria angustifolia 220 days after pruning $(\mathrm{A}=$ Number of shoots and $\mathrm{B}=\%)$. Where: Plagio = plagiotropic shoots; $\mathrm{SD}=$ undefined shoots; Ortho $=$ orthotropic shoots. Means followed by the same uppercase letter between different growth habits and low case letter between prune sizes do not differ (Tukey test at 5\%).

Figura 3 - Hábito de crescimento das brotações de ramos de Araucaria angustifolia aos 220 dias após a poda (A = Número de brotações e $B=\%$ ). Onde: Plagio = brotações plagiotrópicas; $S D$ = brotações sem definição e; Orto = brotações ortotrópicas. Médias seguidas pela mesma letra maiúscula entre os diferentes hábitos de crescimento e minúscula entre os tamanhos de poda não diferem entre si pelo teste de Tukey a 5\%. 
survival ranged from $12 \%\left(1\right.$ g.L $\left.\mathrm{L}^{-1}\right)$ to $30 \%$ (water), with an average reduction of $7.6 \%$ compared to shade house. The number of shoots per cutting did not vary significantly with the application of IBA during the rooting phase, with averages of 6.6 in the SCV, 4.0 in the SCS and 2.8 in the APS (no significant difference between treatments - data not shown). Comparing immersion of the cuttings in ethanol + water (50:50 by volume) and water only, it can be seen that survival and rooting have a similar pattern, indicating that there are no obvious toxic effects of applying alcohol to the base of the cuttings.

Determination coefficients $\left(\mathrm{R}^{2}\right)$ of cuttings height and diameter during the final evaluation in the APS showed extremely low values, suggesting that regression equations are unable to explain the responses of characteristics assessed for IBA applications. Mean values were $17.7 \mathrm{~cm}$ in height and $6.8 \mathrm{~mm}$ in diameter (data not shown).

\subsection{Experiment IV - Rooting cuttings from crown shoots}

Cutting survival at the greenhouse exit was high, ranging from 88 to $100 \%$, regardless of treatment and evaluated trees. In general, the values of rooting in full sunlight area were low, and IBA application did not enhance rooting except for matrix $B$, which gave an increase of about $4 \%$ with the application of 2 and 4 g.L $\mathrm{L}^{-1}$, i.e., rooting of 8 and $12 \%$ over the non-application. In tree $\mathrm{C}$, the application of IBA resulted in decreased rooting, i.e. $28 \%$ without application to 4 and $8 \%$ with application of 2 and 4 g. $\mathrm{L}^{-1}$, respectively. Therefore, there is clearly wide variation in rooting response and the application of IBA between parent trees - with no rooting at all in tree $\mathrm{A}$. The average length of exposed roots in the lower portion of the tube at the greenhouse exit showed no effect of IBA, with a mean value of $4.2 \mathrm{~cm}$, regardless of the treatment (data not shown).

\section{DISCUSSION}

The development of shoots by forest species is a key feature for obtaining viable propagules for use in clonal multiplication techniques. Burrows et al. (1988, 2002) emphasize that plants of the genus Araucaria, unlike most conifers, retain the ability to issue basal shoots with juvenile morphology when mature trees are cut close to ground level. In the present study this feature was confirmed for Araucaria angustifolia.
We were able to compare two techniques for obtaining vegetative propagules, coppicing and pruning primary branches (i.e., directly on crown of the tree), both of which may have important implications for rescuing adult plants for various purposes, including breeding and conservation genetics.

The observed mortality of $40 \%$ of trees subjected to coppicing may be related to the shade provided by the surrounding trees, a key factor for obtaining

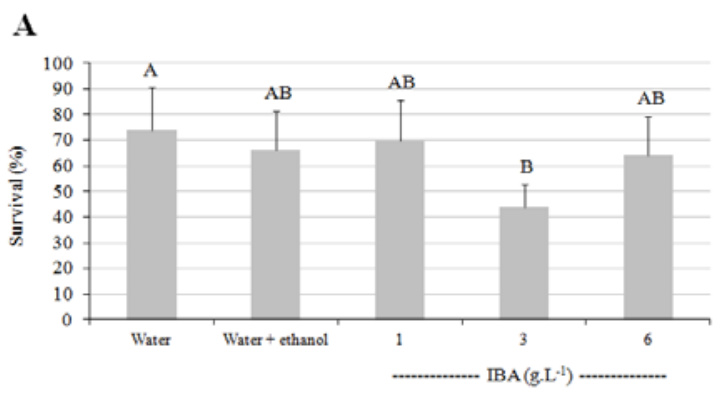

B

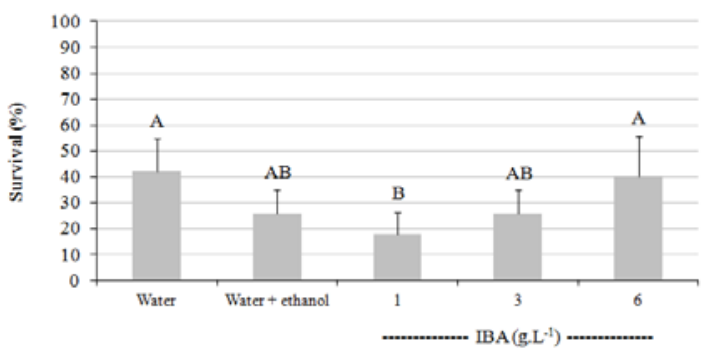

C

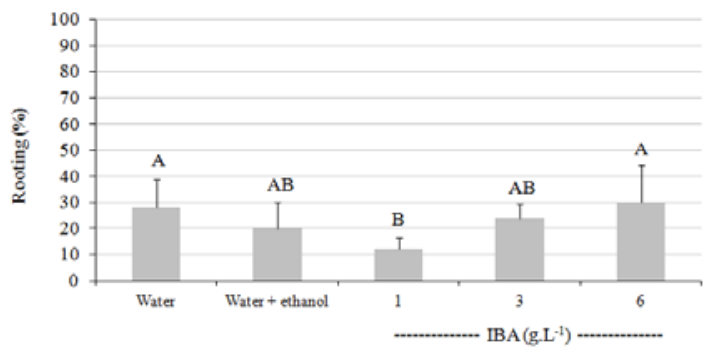

Figure 4 - Survival at greenhouse (A) and shade house exit (B) and rooting in full sunlight area (C) of Araucaria angustifolia cuttings originated from stump shoots, for different IBA concentrations.

Figura 4 - Sobrevivência na saída da casa de vegetação (A), casa de sombra (B) e enraizamento em área de pleno sol (C) de estacas de Araucaria angustifolia, oriundas de brotações de cepas, em função de diferentesconcentrações de AIB. 
shoots from trees (SAMPAIO et al., 2005). Other potential causes of mortality include time of year, the height of the cut (BORGES JUNIOR et al., 2004; PERRANDO and CORDER, 2006) and the age of the trees (PERRANDO and CORDER, 2006; HARTMANN et al., 2011). However, clarifying the causes of shooting failure is not an easy task, given the many factors that may be involved (STURION and HIGA, 1997).

Plagiotropism in araucaria is also a great challenge that needs to be overcome (OLIVEIRA, 2010; WENDLING, 2011). For example, it has been observed that rooted cuttings of primary branches still had horizontal growth four years after planting (OLIVEIRA, 2010), preventing the development of normal plants. In the present study we obtained $90 \%$ of orthotropic shoots after coppicing (Experiment I), and only 44\% after pruning (Experiment II). However, pruning produced almost four times the total amount of orthotropic cuttings per tree, the ultimate goal of these vegetative rescue technologies.

Pruning also resulted in a reasonable proportion (31\%) of shoots without definition (Figure 3B). These are problematic, since it is not known if they will become plagiotropic or orthotropic. Plagiotropic growth refers to growth of vegetatively produced plants that deviates from vertical (orthotropic) and which continues to form a lateral branch (ZOBEL and TALBERT, 1984). However, there are no studies attempting to characterize these morphological and physiological habits, making it difficult to identify shoots that are not clearly orthotropic or plagiotropic (without definition).

Probably the most important factor in the production of shoots and cuttings from pruned branches is the availability of light, similar to results shown in araucaria seedlings by Löwe and Dillenburg (2011). This can be enhanced in the field by wider spacing of trees in single line, in contrast to the high density planting $(3 \times 2 \mathrm{~m})$ seen in the coppiced trees. Pruned branches produced more shoots and cuttings than coppiced trees, taking into consideration the larger area of remaining stem with needles and the presence of preformed trace buds that is characteristic of the Araucariaceae (BURROWS, 1990, 2002) in general, and Araucaria angustifolia specifically. In this species the initial meristematic axillary buds can be found in all needles (FINK, 1983). These results are similar to the observations of Wendling et al. (2009), and indicate that pruning is a viable alternative for obtaining shoots in this species.

No significant differences were observed between coppiced trees of different sexes in relation to total cuttings produced, although there was an increase in apical cuttings production in male plants and nonapical in females (Figure 1B). By contrast, female trees produced a larger number of total shoots and had a higher production of small shoots (Class 1) (Figure $1 \mathrm{~A})$, possibly indicating greater vigor of this sex. This result is consistent with Zanon et al. (2009), who found a greater number of female trees in large diameter classes in an araucaria plantation, although there was no significant difference in mean diameter between male and female plants. It is also consistent with results from studies of Ilex paraguariensis, another dioecious plant, where female trees produced on average $15.1 \%$ more leaf mass than males at five years and eight months of age (STURION et al., 1995).

In general, stump survival and cuttings production is low compared to other species, such as Eucalyptus (HIGA and STURION, 1997; ALMEIDA et al., 2007). Moreover, araucaria produces about $10 \%$ of plagiotropic shoots, which are inappropriate for cuttings aimed at timber production (WENDLING et al., 2009), although these can be used in grafting for seed production. Apical shoots are typically used as cuttings for araucaria (IRITANI et al., 1983; 1986), but no comparative studies have been made between cutting types. In other forest species some studies indicate no difference in rooting between apical and non-apical cuttings (XAVIER et al., 2003), while others suggest that apical cuttings produce better results (RIECKERMANN et al., 1999), suggesting the need for further studies in araucaria.

From the aspect of handling and managing cuttings in clonal multiplication systems (i.e., cuttings and minicuttings techniques) it is desired to obtain a greater amount of apical cuttings rather than non-apical ones (HOUSE et al., 1998), since in apical cuttings there is no need of removing the apex, and also less propensity to form rooted cuttings with multiple shoots, reducing hand labor in the nursery production system.

Rooting is one of the critical aspects of vegetative propagation (XAVIER et al., 2009). In general, the rates of rooting obtained in this study were low when

Revista Árvore, Viçosa-MG, v.39, n.1, p.93-104, 2015 
compared with other forest species with established production systems such as Eucalyptus (ALMEIDA et al., 2007; XAVIER et al., 2009) and Ilex paraguariensis (BITENCOURT et al., 2009; WENDLING et al., 2013). In conifers of the genus Pinus, vegetative propagation by cuttings has been studied for several decades and, in general, the species of this genus are considered as difficult to root. Indeed, rooting is virtually impossible in a large number of them when the plant material has not originated from seedlings (XAVIER et al., 2009). In the present study, a rooting success of 12 to $30 \%$ (stump shoots - Figure 4C) and 0 to $28 \%$ (shoots of crown branches) are still slightly higher than those available in the literature ( 0 to $19.4 \%$ ) for araucaria (TESSDORFF, 1968; IRITANI et al., 1986). It should be also noted that the present study used adult trees (26 and 20 years old respectively for stump and branch shoots), in which the morphogenic capacity is smaller (HACKETT and MURRAY, 1993; HARTMANN et al., 2011 ) than young plants (seed origin).

The higher rooting of cuttings originating from stumps was anticipated, since the base of the tree is a region where the tissues are more juvenile and more prone to adventitious rooting and growth vigor (HACKETT and MURRAY, 1993; HARTMANN et al., 2011; PIJUT et al., 2011). Also, according to this hypothesis, the use of more mature propagules near the apical meristem for vegetative propagation results in earlier flowering and lower canopy height characteristics shown in araucaria by Wendling (2011). Thus, the two vegetative rescue techniques developed for araucaria may have different important applications. Plants derived from stumps are potentially more appropriate for the wood production while those derived from pruning may be better for the creation of pine nut orchards (Figure 5).

There was a significant overall reduction in survival between the greenhouse exit and the effective rooting in the full sunlight area for cuttings derived from both stumps (Figure 4A) and crowns. However, in shoots derived from stumps the reduction was less pronounced than those from crown. This may be an indicative of benign conditions in the rooting environment, where even shoots without roots survived well. It may also be a result of an increased reactive capacity of basal propagules (more juvenile) and rooting recalcitrance of most adult plants (HACKETT and MURRAY, 1993).
The non-toxic effects of the alcohol applied to the base of the cuttings is a good indication that it can be used freely for vegetative propagation - it has traditionally been used for dilution of IBA prior to its application to cuttings and minicuttings (ALMEIDA et al., 2007; BITENCOURT et al., 2009; FERREIRA et al., 2010). In general, no significant effects of IBA application were observed (Figure 4A, 4B and 4C). This response may be related to the physiological characteristics of the cuttings (ELDRIDGE et al., 1994). For example, in this case the relationship between auxin/cytokinin may not be a limiting factor for induction of adventitious roots (PIJUT et al., 2011). The apparent toxicity of IBA application to tree $\mathrm{C}$, even in relatively low concentrations, needs to be further investigated: for species of low rooting ability, these concentrations usually do not cause this effect (FERREIRA et al., 2009; LOPES et al., 2011). The occurrence of variation in hormone response between genotypes is clear and universally accepted (HARTMANN et al., 2011), and therefore will not be discussed here.

For commercial propagation of forest species for wood production, shoots from field have only been used to obtain initial rooted cuttings for minicutting technique (ASSIS et al., 2004), which shows a series of advantages over the first, particularly with respect to higher percentage of rooting and final multiplication rates (ASSIS etal., 2004; XAVIER etal., 2009). For araucaria, minicuttings technique has been developed with good success for juvenile propagules derived from seedlings (PIRES, 2012), which is an excellent indication of the potential suitability of adults for vegetative propagation. For seeds production, on the other hand, the technique with larger application in forest species is grafting (ROCHA et al., 2002) with the use of adult propagules from the crown. This technique is still under development in araucaria, although important results have already been obtained (ZANETTE et al., 2011; WENDLING, 2011).

\section{CONCLUSION}

Based on the foregoing discussion, we suggest that the first rescue technique (shoots from stumps) is most appropriate for producing cuttings to support the development and subsequent commercial use of the minicutting process. In contrast, the second method (shoots from crown branches) is most appropriate to provide propagules for grafting to form orchards for early Brazilian pine nut production, generating shorter plants with known gender and nuts quality. 


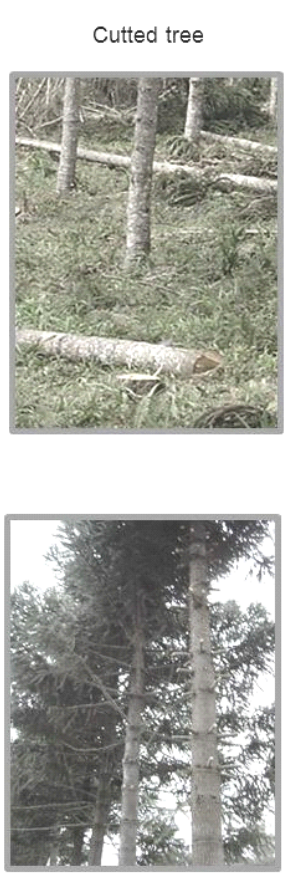

Cut lateral branches
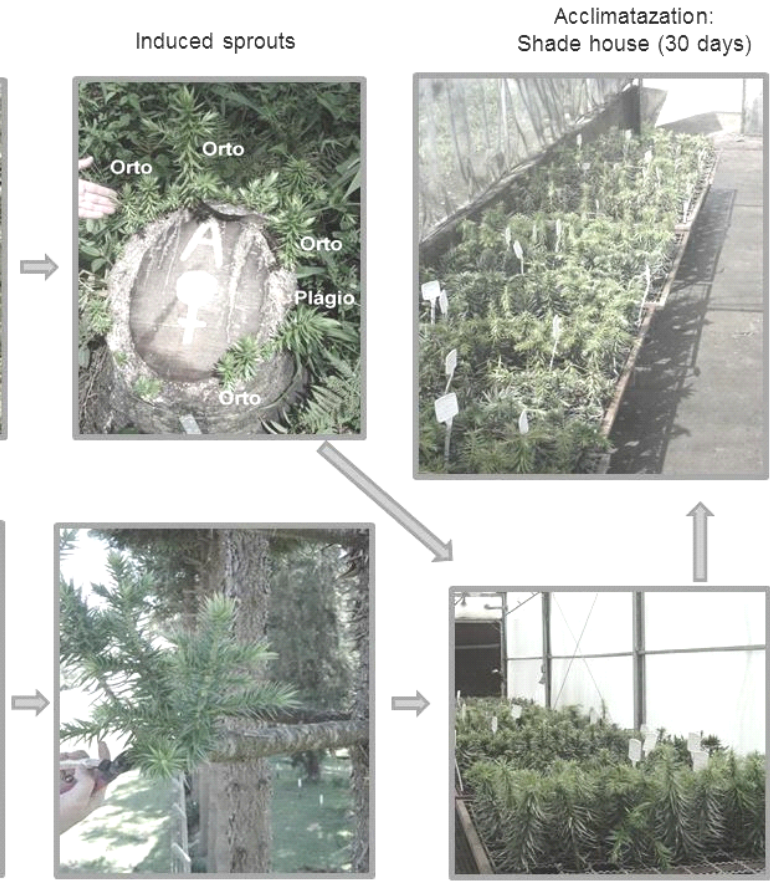

Induced sprouts

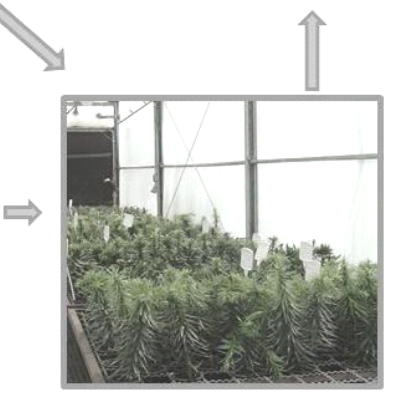

Rooting:

Greenhouse (90 days)

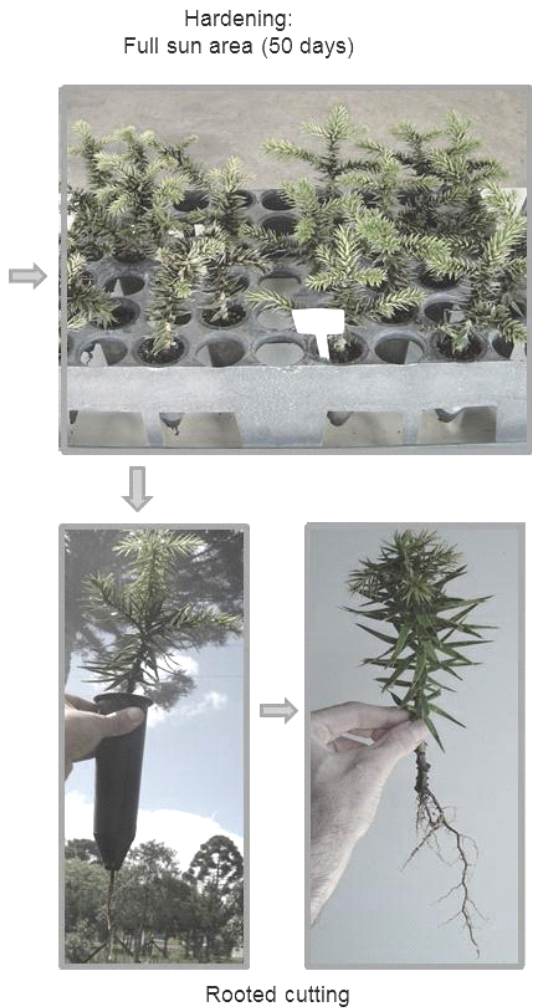

Figure 5 - Sequence diagram of the rescue and cutting process of Araucaria angustifolia used in this study.

Figura 5 - Sequência esquemática do processo de resgate e estaquia de Araucaria angustifolia utilizado no presente estudo.

\section{REFERENCES}

ALMEIDA, F. D.; XAVIER, A.; DIAS, J. M. M. Propagação vegetativa de árvores selecionadas de Eucalyptus cloeziana F. Muell. por estaquia. Revista Árvore, v.31, n.3, p.445453, 2007.

ASSIS, T. F.; FETT-NETO, A. G.; ALFENAS, A. C. Current techniques and prospects for the clonal propagation of hardwoods with emphasis on Eucalyptus. In: WALTER, C.; CARSON, M. (Ed.). Plantation Forest Biotechnology for the 21st Century, 2004. p.303-333. (Research Signpost: Kerala).

BASAK, U. C.; DAS, A. B.; DAS, P. Rooting response in stem cuttings from five species of mangrove trees: effect of auxins and enzyme activities. Marine Biology, v.136, n.1, p.185189,2000

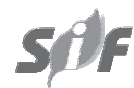

BITENCOURT, J.; RIBAS, K. C. Z.; WENDLING, I.; KOELER, H. Enraizamento de estacas de erva-mate (Ilex paraguariensis A. St.-Hill.) provenientes de brotações rejuvenescidas. Revista Brasileira de Plantas Medicinais, v.11, p.277-281, 2009.

BORGES JÚNIOR, N.; MARTINS-CORDER, M. P.; SOBROSA, R. C.; SANTOS, E. M. Rebrota de cepas de árvores adultas de acácia-negra (Acacia mearnsii De Wild.). Revista Árvore, v.28, n.4, p.611-615, 2004.

BURROWS, G. E. Agathis, Araucaria and Wollemia all possess unusual meristems in their leaf axils. Araucariaceae: In: WILCOX, M. D.; BELESKI, R. L. (Ed.). Araucariaceae. ARAUCARIACEAE SYMPOSIUM (Araucaria, Agathis, Wollemia), 2002, Auckland.

Proceedings... Auckland: 2002.p.87-94.

Revista Árvore, Viçosa-MG, v.39, n.1, p.93-104, 2015 
BURROWS, G. E. Anatomical aspects of root bud development in hoop pine (Araucaria cunninghamii). Australian Journal of Botany, v.38, n.1, p.73-78, 1990.

BURROWS, G. E.; DOLEY, D. D.; HAINES, R. J.; NIKLES, D. G. In vitro propagation of Araucaria cunninghamii and other species of the Araucariaceae via axillary meristems. Australian Journal of Botany, v.36, n.6, p.665-676, 1988.

CARVALHO, P. E. R. Espécies arbóreas brasileiras. Brasília: Embrapa Informação Tecnológica; Colombo: Embrapa Florestas, 2003. 1039p.

CHALUPA, V. In vitro propagation of mature trees of Sorbus aucaparia L. and field performance of micropropagated trees. Journal of Forest Science, v.48, n.12, p.529-535, 2002.

CUEVAS-PÉREZ, F. E.; GUIMARÃES, E. P.; BERRÍO, L. E.; GONZÁLEZ, D. I. Genetic base of irrigated rice in Latin America and the Caribbean, 1971 to 1989. Crop Science, v.32, p.1054-1059, 1992.

DUARTE, L. S.; DILLENBURG, L. R.; ROSA, L. M. G. Assessing the role of light availability in the regeneration of Araucaria angustifolia (Araucariaceae). Autralian Journal of Botany, v.50, p.741-751, 2002.

ELDRIDGE, K.; DAVIDSON, J.; HARDWIID, C.; van WYK, G. Eucalypt domestication and breeding. Oxford: Clarendon Press, 1994. p.228-246.

FERREIRA, B. G. A.; ZUFFELLATO-RIBAS, K. C.; CARPANEZZI, A. A.; TAVARES, F. R.;

KOEHLER, H. S. Metodologias de aplicação de AIB no enraizamento de estacas semilenhosas de Sapium glandulatum (Vell.) Pax. Revista Brasileira de Plantas Medicinais, v.11, n.1, p.196-201, 2009.

FERREIRA, B. G. A.; ZUFFELLATO-RIBAS, K. C.; WENDLING, I.; KOEHLER, H. S.; NOGUEIRA, A. C. Miniestaquia de Sapium glandulatum (Vell.) Pax com o uso de ácido indolbutírico e ácido naftaleno acético. Ciência Florestal, v.20, p.19-31, 2010.

Revista Árvore, Viçosa-MG, v.39, n.1, p.93-104, 2015
FINK, S. The occurrence of adventitious and preventitious buds within the bark of some temperate and tropical trees. American Journal of Botany, v.70, n.4, p.532-542, 1983.

HACKETT, W. P.; MURRAY, J. R. Maturation and rejuvenation in woody species. In: AHUJA, M. R., (Ed.) Micropropagation of woody

plants. Dordrecht: Kluwer Academic Publishers, p.93-105, 1993.

HARTMANN, H. T.; KESTER, D. E.; DAVIES JR, F. T.; GENEVE, R. L. Plant propagation: principles and practices. 8 ed. São Paulo: PrenticeHall, 2011.915p.

HIGA, R. C. V.; STURION, J. A. Capacidade de brotação em subgêneros e espécies de Eucalyptus. Série Técnica IPEF, v.11, n.30, p.23-30, 1997.

HOUSE, S.; DIETERS, M.; JOHNSON, M.; HAINES, $\mathrm{R}$. Inhibition of orthotropic replacement shoots with auxin treatment on decapitated hoop pine, Araucaria cunninghamii, for seed orchard management. New Forests, v. 16, p.221-230, 1998.

IRITANI, C.; SOARES, R. V. Indução do enraizamento de estacas de Araucaria angustifolia através da aplicação de reguladores de crescimento. Silvicultura, v.8, n.28, p.313317,1983 .

IRITANI, C.; SOARES, R. V.; GOMES, A. V. Aspectos morfológicos da ação dereguladores do crescimento em estacas de Araucaria angustifolia (Bert) O. Ktze. Acta Biológica Paranaense, v. 15, n.1/2/3/4, p.1-20, 1986.

IUCN Red List of Threatened Species. Version 2013.2. www.iucnredlist.org>. Downloaded on 10 May 2013

LI, S. W.; XUE, L.; XU, S.; FENG, H.; AN, L. Mediators, genes and signaling in adventitious rooting. The Botanical Review, v.75, n.2, p.230-247, 2009.

LOPES, V. R.; MUNDRY, C. S.; BENTONNI, M. M.; ZUFFELLATO-RIBAS, K. C. Enraizamento de estacas caulinares de Ficus benjamina L. sob diferentes concentrações de ácido indolbutírico. Scientia Agraria, v.12, n.1, p.1-15, 2011. 
LÖWE, T. R.; DILLENBURG, L. R. Changes in light and nutrient availabilities do not alter the duration of use of seed reserves in Araucaria angustifolia seedlings. Australian Journal of Botany, v.59, p.32-37, 2011.

MOREIRA-SOUZA, M.; CARDOSO, E. J. B. N. Practical method for germination of Araucaria angustifolia (Bert.) O. Ktze. seeds. Scientia Agricola, v.60, n.2, p.389-391, 2003.

OLIVEIRA, L. S. Enxertia, microenxertia e descrição do tropismo em Araucaria angustifolia (Bert.) O. Ktze. 2010. 90f. Tese (Doutorado em Ciências Agrárias) - Setor de Ciências Agrárias, Universidade Federal do Paraná, Curitiba, 2010.

PERRANDO, E. R.; CORDER, M. P. M. Rebrota de cepas de Acacia mearnsii em diferentes idades, épocas do ano e alturas de corte. Pesquisa Agropecuária Brasileira, v.41, n.4, p.555$562,2006$.

PIJUT, P. M.; WOESTE, K. E.; MICHLER, C. H. Promotion of adventitious root formation of difficult-to-root hardwood tree species.

Horticultural Reviews, v.38, p.213-251, 2011.

PIRES, P. P. Sazonalidade e soluções nutritivas na miniestaquia de Araucaria angustifolia (Bert.) O. Ktze. em propágulos de origem seminal. 2012. $81 \mathrm{f}$. Dissertação (Mestrado em Engenharia Florestal) Universidade Federal do Paraná, Curitiba, 2012.

RIECKERMANN, H.; GOLDFARB, B.; CUNNINGHAM, M. W.; KELLISON, R. C. Influence of nitrogen, photoperiod, cutting type, and clone on root and shoot development of rooted stem cuttings of sweetgum. New Forests, v.18, n.3, p.231-244, 1999.

ROCHA, M. G. B.; ROCHA, D.; CLEMENTE, V. M.; FREITAS, M. V.; GOMES, R.; JESUS, S. V.; CHAVES, R. M.; TORRES, G. A.; XAVIER, A. Propagação vegetativa de espécies arbóreas nativas. In: ROCHA, M. G. B. Melhoramento de espécies arbóreas nativas. Belo
Horizonte: Instituto Estadual de Florestas, 2002. p.91-108.

SAMPAIO, P. T. B.; BARBOSA, A. P.; VIEIRA, G.; SPIRONELLO, W. R.; BRUNO, F. M. S. Biomassa da rebrota de copas de pau-rosa (Aniba rosaeodora Ducke) em plantios sob sombra parcial em floresta primária. Acta Amazonica, v.35, n.4, p.491-494, 2005.

SOUSA, V. A.; HATTEMER, H. H. Pollen dispersal and gene flow by pollen in Araucaria angustifolia. Australian Journal of Botany, v.51, p.309-317, 2003.

WENDLING, I.; BRONDANI, G. E.; BIASSIO, A.; DUTRA, L. F. Vegetative propagation of adult Ilex paraguariensis trees through epicormic shoots. Acta Scientiarum Agronomy, v.35, n.1, p.117-125, 2013.

WENDLING, I.; DUTRA, L. F.; HOFFMANN, H. A.; BETTIO, G.; HANSEL, F. Indução de brotações epicórmicas ortotrópicas para a propagação vegetativa de árvores adultas de Araucaria angustifolia. Agronomía Costarricense, v.33, n.2, p.309-319, 2009.

WENDLING, I. Enxertia e florescimento precoce em Araucaria angustifolia. Embrapa Florestas, 2011 (Comunicado Técnico 272).

XAVIER, A.; SANTOS, G. A. Clonagem em espécies florestais nativas. In: ROCHA, M. G. B. (Ed.) Melhoramento de espécies arbóreas nativas. Belo Horizonte: Instituto de Estudos Florestais, 2002. 173p.

XAVIER, A.; SANTOS, G. S.; OLIVEIRA, M. L. Enraizamento de miniestaca caulinar e foliar na propagação vegetativa de cedro-rosa (Cedrela fissilis Vell.). Revista Árvore, v.27, n.3, p.351-356, 2003.

XAVIER, A.; WENDLING, I.; SILVA, R. L. Silvicultura clonal: princípios e técnicas. Viçosa, MG: Universidade Federal de Viçosa, 2009. v.1.272p.

ZANETTE, F.; OLIVEIRA, L. S.; BIASI, L. A. Grafting of Araucaria angustifolia through the four seasons of the year. Revista Brasileira de Fruticultura, v.33, n.4, p.1364-1370, 2011. 
ZANON, B.; LEA, M.; FINGER, C.A.G.;

SCHNEIDER, P. R. Proporção da dioicia e

distribuição diamétrica de árvores masculinas e femininas de Araucaria angustifolia (Bertol.)

Kuntze, em povoamentos implantados. Ciência

Florestal, v.19, n.4, p.425-431, 2009. 